УДК 621.77

\author{
К.В. Волков ${ }^{1}$, М.В. Филиппова ${ }^{2}$ В.Н. Перетятько \\ ${ }^{1}$ ЕВРАЗ Объединенный Западно-Сибирский металлургический комбинат \\ ${ }^{2}$ Сибирский государственный индустриальный университет
}

\title{
ПРОКАТКА РАЗДЕЛЕНИЕМ
}

Продольное разделение заготовки в процессе прокатки является эффективной технологией, позволяющей снизить материальные и энергетические затраты, а также увеличить производительность прокатных станов. Сущность этого способа прокатки заключается в формировании в подготовительном калибре раската, состоящего из нескольких профилей, соединенных перемычками. В последующем разделительном калибре осуществляется их разделение. Дальнейшая многониточная прокатка производится в одноручьевых калибpax.

В настоящее время продольное разделение проката в потоке стана реализуется по двум схемам: 1 - формирование сочлененного проката и продольное разделение его в валках прокатного стана; 2 - формирование сочлененного проката и его продольное разделение неприводным делительным инструментом.

Для исследования продольного разделения сочлененного профиля в валках прокатного стана проведено компьютерное моделирование с использованием пакета Deform 3D. Модель раската сочлененного профиля имела вид двух квадратов со стороной 11,5 мм и толщиной перемычки 7,0 мм при моделировании прокатки-разделения арматуры № 10 и стороной квадрата 14,0 мм, соединенных перемычкой 8,0 мм при моделировании арматуры № 12. В разделительном калибре получали два соединенных перемычкой толщиной 1,0 мм квадрата со стороной 11,0 и 13,5 мм при прокатке арматуры № 10 и 12 соответственно.

Условия моделирования: сталь марки Ст3пс; температура $1000{ }^{\circ} \mathrm{C}$; коэффициент трения 0,5 ; скорость прокатки $10 \mathrm{~m} / \mathrm{c}$.
Результаты $\left(H_{n}\right.$ и $H_{p}$ - толщина перемычки до и после разрезки; $\varepsilon_{i}-$ интенсивность деформаций; $\sigma_{i}-$ интенсивность напряжений; $\sigma_{z}, \sigma_{y}$ и $\sigma_{x}-$ напряжения по вертикали, по ширине и вдоль направления прокатки) компьютерного моделирования напряженно-деформированного состояния центрального слоя по оси разрезки приведены ниже:

\begin{tabular}{ccc} 
Показатель & \multicolumn{2}{c}{ Значение показателя } \\
$H_{n}$, мм & 7,0 & 8,0 \\
$H_{p}$, мм & 1,0 & 1,1 \\
$\varepsilon_{i}$ & 1,30 & 1,98 \\
$\sigma_{i}$, Па & $9,32 \cdot 10^{7}$ & $6,8 \cdot 10^{7}$ \\
$\sigma_{z}$, Па & $-2,26 \cdot 10^{8}$ & $-1,13 \cdot 10^{8}$ \\
$\sigma_{y}$, Па & $-2,28 \cdot 10^{8}$ & $-5,14 \cdot 10^{7}$ \\
$\sigma_{x}$, Па & $-1,34 \cdot 10^{8}$ & $-4,15 \cdot 10^{7}$
\end{tabular}

Можно отметить, что все нормальные напряжения по координатным осям отрицательны. Таким образом, напряженное состояние металла при разрезке перемычки является всесторонним сжатием. В таких условиях деформации происходит только передавливание металла перемычки без его разрушения. Для гарантированного разделения проката желательно использовать неприводной делительный инструмент, установленный после клети с разделительным калибром.

(C) 2012 г. К.В. Волков, М.В. Филиппова, В.Н. Перетятько Поступила 30 мая 2012 г. 